\section{Hjertegodt om hjertesykdom}

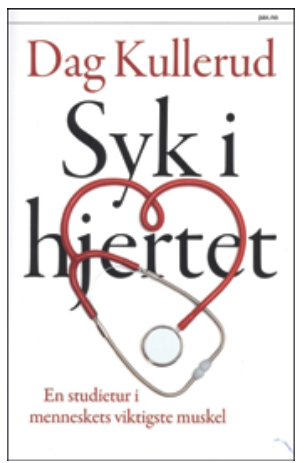

Dag Kullerud

Syk i hjertet

En studietur i menneskets viktigste muskel. 186 s, ill. Oslo: Pax Forlag, 2011. Pris NOK 299 ISBN 978-82-530-3436-2

Målgruppen er et bredt publikum, og leseren får et godt innblikk $i$ hvordan livet endrer seg ved akutt sykdom. I tillegg er boken faglig interessant for tidligere hjertepasienter og helsepersonell som ikke arbeider i feltet. Alle disse lesergruppene, men spesielt helsepersonell og tidligere pasienter, vil nikke gjenkjennende til beskrivelsene av sykehusmiljøet, med både gleder, sorger og enkelte ubehagelige situasjoner mellom pasient og personale.

Teksten er skrevet ut fra personlige erfaringer med sykdom og helsevesen, men har også et tydelig faglig innhold som i hovedsak er forfatterens gjengivelse av fagfolkenes beskrivelse av sykdom, årsakssammenheng og behandling. Det er også hentet inspirasjon til disposisjon av stoffet fra andre som har skrevet om egne erfaringer med hjertesykdom. Boken er lettlest, og hvert kapittel innehar sin egen historie og avgrensning slik at det er lett å ta opp tråden igjen etter pauser i lesingen.

Sykdommen startet med hjerteinfarkt og hjertestans og dertil hørende dramatiske opplevelser og avansert behandling. Det meste er rutine for helsepersonellet, men de eksistensielle tankene hos pasienten får god plass og gjør inntrykk.

Del 2 om symptomer og egne opplevelser av sykdom er spennende, forfatteren reiser gode spørsmål og velfundert tvil. Svakhetene ved dagens kardiologiske diagnostikk er realistiske, og det er en åpenhjertig omtale av det å være korridorpasient bak et skjermbrett, og støynivået der.

I del 3 har forfatteren på relativt kort tid fått med seg mye av det pulserende livet. Det er observante beskrivelser av legevisittene, systemene, kostholdet, portørene og det å bli trillet rundt i seng til forskjellige undersøkelser. Rådet om å holde seg inne med utvalgte sykepleiere er kostelig - og lett gjenkjennelig som en ofte sikker farbar vei for å bli ivaretatt gjennom systemet, spesielt under langtrukne forløp.

Del 4 og 5 omhandler hjerteinngrep, pårørendes situasjon, samliv, rehabilitering, kostholdsråd og om å forstå sykdom. Det er til dels noen unødvendige detaljer om hjerteblokking som ikke treffer noen av målgruppene, det blir for enkelt for fagfolk og for vanskelig og uinteressant for andre. Hjertet som metafor for sider av det menneskelige vesen, inneholder interessante vinklinger og anekdoter. Den anatomiske tegningen med dikt av Wergeland og gjengivelse av den danske forfatteren Seeberg er morsomt, men kanskje litt på siden. Beskrivelsen av opplevelsen rundt hjerteoperasjonen er både morsom og svært realistisk, det samme gjelder fagdiskusjonen som pågikk i forkant med temperatur og uenigheter blant fagfolkene.

Boken er skrevet både for å gi et innblikk i fagfeltet og ut fra egne eksistensielle betraktninger og personlige observasjoner. Det er de personlige aspektene og vinklingen som gir den største og mest varige gleden og ettertanken for leseren. Dette er en hjertegod bok.

\section{Jan Erik Nordrehaug}

Hjerteavdelingen

Haukeland universitetssykehus

\section{Godt om veiledning}

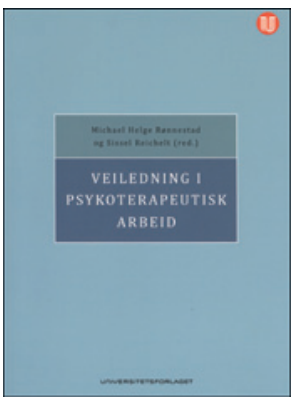

Michael Helge Rønnestad, Sissel Reichelt, red.

\section{Veiledning i psykoterapeutisk arbeid}

236 s, ill. Oslo: Universitetsforlaget, 2011.

Pris NOK 399

ISBN 978-82-15-01756-3

Klinisk samtalemetodikk læres gjennom å snakke med pasienter og reflektere over prosessen i samspillet. Profesjonell utvikling forutsetter at kandidaten åpner seg for kompleksiteten og de ulike lagene i dette samspillet og i sin relasjon til pasienten, og reflekterer over sine erfaringer sammen med veileder. Den kliniske veiledningen vil følgelig ha som mål å styrke kandidatens ferdigheter i å gjennomføre samtaler og undersøkelser, i å kunne analysere og forstå pasientens problem og sette det inn i en teoretisk ramme samt i å håndtere vanskelige følelser hos kandidaten selv og hos pasienten. Veiledningens teori og pedagogikk er temaet for denne boken.

Forfatterne er en rekke svært erfarne kliniske psykologer, og de gir her først og fremst et teoretisk fundament for veiledning av ulike psykoterapeutiske metoder. Boken omhandler først veiledningens rammebetingelser. Forfatterne legger stor vekt på betydningen av at kandidaten vet hva som ventes av henne, og hvordan arbeidet skal foregå. Deretter gjennomgås hvordan veiledningen bør være i ulike faser av den profesjonelle utviklingen. Etter dette drøftes veiledningen i forhold til ulike psykoterapeutiske tilnærminger, blant annet kognitiv, psykodynamisk, systemorientert, familie- og gruppeterapi. Både individuell veiledning og gruppeveiledning beskrives, før det gis en oversikt over veiledningsforskningen, etiske og juridiske rammer for veiledning og utdanning av veiledere.

Boken er skrevet av og for psykologer, og eksemplene er hentet fra psykologers og særlig psykologistudenters praksis. Det gjør at enkelte kapitler eller deler av disse blir noe mindre interessante for leger. Men i hovedsak tar forfatterne opp sider ved veiledning som er relevant ikke bare for psykoterapiveiledere, men for alle som gir klinisk veiledning i medisin. Den kan leses fra perm til perm, men kan også fungere som en bok man slår opp i for å minne seg selv om sentrale sider ved veiledningsprosessen.

Selv kommer jeg til å gå tilbake til Rønnestad og Skovholts empiritunge kapittel om terapeuters profesjonelle utvikling, Løvlie Schibbyes innsiktsfulle kapittel om veiledning i et relasjonsperspektiv, Gullestads kapittel om veiledning av psykodynamisk psykoterapi og Skjerves omtale av sosiale rollemodeller for veiledning. Boken er teoritung og suppleres på en glimrende måte av en mer praksisnær bok om veiledning som jeg nylig har omtalt (1).

Veiledning har en sentral betydning for kandidatens profesjonelle utvikling, og det er derfor viktig at alle som driver med klinisk veiledning, har et reflektert forhold til denne oppgaven. Har du ansvar for å veilede yngre kolleger i deres profesjonelle utvikling som terapeuter, utgjør nok innholdet et minimum av hva du bør kjenne til om veiledningens teori og metodikk.

\title{
Per Vaglum
}

Avdeling for medisinske atferdsfag

Institutt for medisinske basalfag

Universitetet i Oslo

\section{Litteratur}

1. Vaglum P. Inspirerende og praksisnært om veiledning. Anmeldelse av: Karlsson BE, Oterholt F. Fenomener i faglig veiledning. Tidsskr Nor Legeforen 2011. 131. $371-2$. 